\title{
Dinamika Forgiveness pada Istri yang Mengalami Kekerasan dalam Rumah Tangga (KDRT)
}

\author{
I DEWA AYU DWIKA PUSPITA DEWI ${ }^{*}$ \& NURUL HARTINI ${ }^{1}$ \\ 1Departemen Psikologi Klinis dan Kesehatan Mental, Fakultas Psikologi Universitas Airlangga
}

\begin{abstract}
ABSTRAK
Tujuan dari penelitian ini adalah untuk mengkaji dinamika forgiveness pada istri yang mengalami KDRT. Penelitian ini menggunakan pendekatan kualitatif dengan metode studi kasus instrumental. Kriteria subjek dalam penelitian ini yaitu seorang istri yang memiliki rentang usia 18-40 tahun, pernah mengalami KDRT oleh suami dan masih bertahan dalam perkawinan. Penelitian ini melibatkan tiga orang subjek yang pernah mengalami KDRT oleh suami dan masih bertahan dalam perkawinan selama 14-25 tahun. Penggalian data pada penelitian ini menggunakan teknik wawancara dan menggunakan teknik analisis tematik theory driven. Hasil dari penelitian menunjukan bahwa istri yang mengalami KDRT sulit memaafkan pelaku karena adanya ruminasi yaitu ingatan terhadap peristiwa KDRT yang pernah dialami dan adanya atribusi serta penilaian negatif mengenai pelaku. Dinamika forgiveness terjadi ketika istri yang mengalami KDRT mengubah dorongan untuk menghindari pelaku dan mengurangi dorongan membalas dendam terhadap pelaku ke arah yang positif melalui akomodasi. Meskipun pelaku meminta maaf atas kesalahannya, namun tidak ditemukan adanya empati untuk memaafkan pasangan. Penelitian ini menemukan adanya dorongan untuk berbuat baik kepada pelaku dengan melayani suami, meskipun demikian hal tersebut merupakan tugas dari seorang istri dalam rumah tangga yaitu untuk melayani suami.
\end{abstract}

Kata kunci: dinamika forgiveness, istri, kekerasan dalam rumah tangga (KDRT)

\section{ABSTRACT}

The objective of this research was to study dynamic of forgiveness on wives experiencing domestic violence. This research used qualitative approach with instrumental case study method. Subject criteria in this research were wives ranging from 18-40 years old, having experience of domestic violence from their husbands and being still in a marriage. This research involved three subjects who used to experience domestic violence from their husband and still in marriage for 14-25 years. Data extraction in this research used interview technique and used theory driven thematic analysis technique. The result of this research indicates that a wife who experiences domestic violence is hard to forgive the abuser due to rumination which is a memory of dynamic violence which has been experienced and there is attribution as well as negative appraisal on the abuser. Dynamic of forgiveness occurs when wives who experience domestic violence change motivation to avoid the abuser and decrease motivation to take revenge on the abuser and change it into positive direction through accommodation. Although the abuser apologizes for his mistakes, there is no empathy found to forgive. This research finds a motivation to do favor to the abuser by serving husband, although that is a duty of a wife in a household.

Keywords: dynamics of forgiveness, wives, domestic violence 
INSAN Jurnal Psikologi dan Kesehatan Mental, 2017, Vol. 2(1), 51-62, doi: 10.20473/jpkm.v2i12017.51-62 Dikirimkan: 8 Mei 2017 Diterima: 31 Mei 2017 Diterbitkan: 26 Juni 2017

Editor: Atika Dian Ariana

*Alamat korespondensi: Jalan Airlangga 4-6, Surabaya, Jawa Timur 60286. Surel: dwika.pd@gmail.com

Naskah ini merupakan naskah dengan akses terbuka dibawah ketentuan the Creative Common Attribution License (http://creativecommons.org/licenses/by/4.0), sehingga penggunaan, distribusi, reproduksi dalam media apapun atas artikel ini tidak dibatasi, selama sumber aslinya disitir dengan baik.

\section{PE N D A H U L U A N}

Komnas Perempuan (2013) menunjukan peningkatan angka kekerasan pada perempuan secara signifikan dari 3.169 kasus pada tahun 2001 hingga mencapai 216.156 kasus pada tahun 2012. Bentuk dari kekerasan terhadap perempuan yang paling sering terjadi adalah kekerasan dalam rumah tangga (KDRT) dibandingkan dengan kekerasan di ranah komunitas. Kasus KDRT di Jawa Timur berdasarkan data dari Kepolisian Negara Republik Indonesia daerah Jawa Timur (POLDA JATIM) adalah sebanyak 214 kasus pada periode Januari hingga Desember 2014 dan sebanyak 105 kasus KDRT pada periode januari hingga agustus 2015. Korban KDRT memiliki beberapa cara untuk menyelesaikan KDRT yang dialaminya yaitu dengan cara bercerai atau pun bertahan dalam perkawinan.

Saraswati (2006) mengungkapkan bahwa keputusan yang paling banyak diambil sebagai solusi korban adalah menempuh jalan perceraian. Data pada tahun 2001 hingga 2005 menunjukan bahwa lebih banyak korban yaitu 66 orang, 36 orang, 77 orang, 70 orang dan 37 orang memiliki keinginan untuk bercerai, banding, menggugat atuapun digugat. Selain itu, data yang diungkapkan juga oleh Komnas Perempuan pada tahun 2012 bahwa seluruh perkara kekerasan yang dialami oleh perempuan di Indonesia, sebanyak 67 persen atau 203.507 diproses dan mendapatkan akta cerai. Selain perceraian, terdapat solusi lain yang ditempuh oleh korban KDRT yaitu melalui musyawarah dengan harapan suaminya akan berubah dan adanya keinginan korban menjaga keharmonisan keluarga. Data menunjukan pada tahun 2004 tercatat sebanyak 124 orang dan 127 orang pada tahun 2005, memilih untuk bertahan dalam rumah tangganya (Saraswati, 2006), dan pada tahun 2014 terdapat 73.3 persen istri yang mengalami KDRT lebih memilih mempertahankan rumah tangganya dan memberikan maaf kepada suami (Sartika \& Amalia, 2014).

Kekerasan yang dialami oleh perempuan dalam rumah tangganya akan mempengaruhi kondisi fisik dan psikologis individu tersebut. Sonda (2010) mengungkapkan bahwa kekerasan fisik yang dialami menyebabkan korban KDRT menjadi stres berkepanjangan, tertekan, merasa malu, rendah diri serta merasa tidak berdaya. Selain itu, dampak fisik yang muncul adalah terganggunya kesehatan reproduksi dan mengalami terlambat haid. Perempuan yang mengalami KDRT merasa pasrah dan tidak berdaya menghadapi situasi yang dihadapinya sehingga menyebabkan perasaan ragu-ragu dalam mengambil keputusan. KDRT merupakan salah satu konflik yang menimbulkan emosi negatif pada seseorang (Silalahi \& Meinarno, 2010). Timbulnya perasaan sedih dan khawatir pada korban akan mendorong seseorang untuk menghindari pelaku dan membalas dendam terhadap pelaku.

Pemaafan merupakan jalan yang dilakukan untuk meredakan dorongan negatif yang dapat merusak hubungan (McCullough, 2001), namun ketika pemaafan tidak dilakukan maka akan menimbulkan interaksi negatif terhadap pasangan seperti adanya penghindaran dan pembalasan kepada pelaku

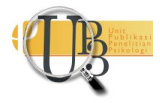


hingga menimbulkan konflik dikemudian hari (Fincham, Davila \& Beach, 2007; Fincham, 2010). Pembalasan yang dilakukan oleh korban KDRT kepada pelaku mengindikasikan bahwasanya terdapat korban yang belum mampu memaafkan suami. Hal tersebut sesuai dengan yang diungkapkan oleh McCullough (2000) bahwa ketika seseorang tidak memaafkan maka terdapat dorongan untuk membalas dendam kepada pelaku. Adanya dorongan negatif akibat tidak dapat memaafkan dapat menjadikan korban sebagai pelaku KDRT di kemudian hari (Smith, 2005).

Berdasarkan uraian masalah diatas, fenomena KDRT yang terjadi di Indonesia menarik untuk diteliti karena selain pilihan untuk bercerai, korban KDRT memilih untuk bertahan dalam perkawinan dan memaafkan perlakuan suami. Pemaafan diketahui dapat memperbaiki hubungan, sedangkan ketika korban KDRT tidak memaafkan suaminya diketahui akan menimbulkan respon emosi negatif seperti adanya rasa marah yang mendorong korban untuk membalas dendam kepada pelaku. Sementara perasaan marah tersebut akan dapat berkurang ketika korban mampu memaafkan pasangan (Enright \& North, 1998). Berdasarkan hal tersebut maka penulis ingin memahami lebih dalam mengenai dinamika forgiveness pada istri yang mengalami KDRT dan bertahan dalam perkawinan.

\section{Kekerasan dalam Rumah Tangga}

Kekerasan dalam rumah tangga atau yang sering disebut dengan domestic violence didefinisikan sebagai pola perilaku yang kejam oleh seseorang terhadap pasangannya dalam hubungan intim seperti perkawinan, pacaran dan keluarga (Chhikara, Jakhar, Malik, Singla, \& Dhattarwal, 2013). Kekerasan dalam rumah tangga menurut Pasal 1 Undang-undang Penghapusan Kekerasan dalam Rumah Tangga adalah:

"Setiap perbuatan terhadap seseorang terutama perempuan, yang berakibat timbulnya kesengsaraan atau penderitaan secara fisik, seksual, psikologis, dan atau penelantaran rumah tangga termasuk ancaman untuk melakukan perbuatan, pemaksaan, atau perampasan kemerdekaan secara melawan hukum dalam lingkup rumah tangga".

Kekerasan dalam rumah tangga di Indonesia merupakan bentuk kekerasan terhadap gender yang selama ini terjadi pada perempuan dan disebabkan oleh adanya konstruksi di masyarakat (Kodir \& Mukarnawati, 2008). Konstruksi budaya di Indonesia yang merendahkan peran gender perempuan menyebabkan perempuan mengalami posisi marjinal dimasyarakat. Ketidakadilan gender merupakan akibat dari struktur sosial dan budaya yang menempatkan relasi gender secara timpang. Adanya ketimpangan terhadap gender, memposisikan laki-laki pada aspek yang selalu mendominasi, sedangkan perempuan diposisikan sebagai seseorang yang lemah dan kurang mandiri. Perbedaan gender tersebut menyebabkan perempuan menjadi korban dalam kekerasan gender (Kodir \& Mukarnawati, 2008).

Kekerasan dalam rumah tangga dapat dijelaskan menggunakan teori lingkaran kekerasan oleh Walker (1979) dalam Walker (1992). Pada tension building phase pelaku melakukan tindak kekerasan ringan yang disebabakn oleh faktor-faktor lain yang dapat menimbulkan perselisihan. Pada fase berikutnya, pelaku kehilangan kontrol dan melakukan KDRT dengan cara memukul, mendorong, menjambak hingga menyeret korban. Kemudian pada fase bulan madu, pelaku menujukan perubahan perilaku, berjanji akan berubah dan meminta maaf kepada korban. Korban akhirnya percaya kepada pelaku dan memaafkan pelaku serta berharap agar pelaku tidak mengulangi perbuatannya. Kekerasan dalam rumah tangga, tidak dapat diprediksi karena merupakan suatu pola yang dilakukan berulang-ulang

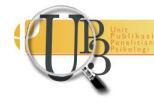


oleh pelaku atau membentuk lingkaran kekerasan meskipun pelaku menunjukan perubahan pada fase bulan madu, namun dikemudian hari akan kembali pada tension building phase dan the acute battering incident phase (Family Crisis Center, 2010).

\section{Forgiveness}

Definisi forgiveness ditemukan memiliki perbedaan antar peneliti di bidang forgiveness (McCullough, 2001). Enright dan the Human Developmental Study Group (1991) berpendapat bahwa forgiveness meliputi keinginan individu untuk melepaskan kebencian, penilaian negatif, dan perilaku acuh tak acuh terhadap orang yang menyakiti, sehingga terbentuk dorongan berupa kasih sayang, kemurahan hati dan cinta terhadap orang yang menyakiti. Enright, Freedman dan Rique (dalam Enright \& North, 1998) mengemukakan bahwa forgiveness adalah respon individu terhadap peristiwa menyakitkan dan hanya terjadi antar manusia, bukan antar manusia dan alam. Peneliti lain dibidang forgiveness mendefinisikan forgiveness sebagai proses mengurangi kebencian didasarkan pada emosi, motivasi, dan kognisi (Worthington, dkk, 2007), serta sebagai peningkat emosi positif dan persepektif seperti empati, harapan, dan kasih sayang (Harris \& Thoresen, 2005).

Forgiveness menurut McCullough (2001) merupakan motivasi individu untuk meredakan kebencian terhadap pihak yang menyakitinya, mengubah individu untuk tidak membalas dendam serta meningkatkan dorongan untuk memperbaiki hubungan dengan pihak yang menyakiti. Forgiveness terdiri dari konstruk motivasi dan perubahan prososial. Forgiveness sebagai motivasi dapat dipahami sebagai respon afektif ketika mengalami peristiwa menyakitkan yang terdiri dari motivasi menghindari dan motivasi untuk membalas dendam kepada pelaku (McCullough, 2000). Pada saat individu memiliki keinginan yang besar untuk menghindari pelaku dan ingin membalas dendam, maka dikatakan bahwa korban belum mampu memaafkan pasangannya dan hal tersebut akan merusak hubungannya dengan pelaku.

Pemaafan terjadi ketika individu mampu meredakan motivasi untuk menghindari pelaku dan motivasi untuk membalas dendam. Ketika individu memaafkan pasangannya, maka akan terjadi peningkatan motivasi untuk berbuat baik atau benevolence motivation terhadap pasangan yang telah menyakiti (McCullough, 1997). Forgiveness juga meliputi perubahan prososial yang terdiri dari: 1) proses akomodasi yang meliputi keinginan untuk menahan dorongan untuk berperilaku destruktif, serta adanya keinginan untuk berperilaku konstruktif pada pasangan yang telah menyakitinya (Rusbult, Verette, Whitney, Slovik, and Lipku, 1991 dalam McCullough 2000) dan 2) adanya keinginan untuk mau berkorban yaitu melupakan kepentingan diri sendiri untuk menjaga keharmonisan hubungan (Van Lange dkk, 1997 dalam McCullough, 2000).

Forgiveness dipengaruhi oleh beberapa faktor, diantaranya: 1) proses kognitif dan emosional yang meliputi empati, dimana ketika individu memiliki empati terhadap pasangan yang telah menyakitinya, maka akan memunculkan keinginan untuk menolong yang kemudian mengarahkan individu untuk memaafkan pasangannya. Proses pemaafaan berkaitan erat dengan adanya empati korban terhadap pasangannya. McCullough (1997) mengungkapkan bahwa empati merupakan fasilitator utama yang menyebabkan seseorang dapat memberikan maaf, 2) kualitas hubungan memiliki pengaruh terhadap pemaafan yang diberikan, hal tersebut disebabkan oleh adanya komitmen, kepuasan hubungan serta kedekatan hubungan dengan pasangan, 3) faktor situasi seperti permintaan maaf dari pasangan akan menimbulkan empati, dan mau memaafkan pasangan, serta 4) adanya pengaruh kepribadian yang dimiliki oleh individu turut serta terlibat dalam pemaafan yang diberikan kepada pasangan INSAN Jurnal Psikologi dan Kesehatan Mental 2017, Vol. 2(1), 51-62

doi: 10.20473/jpkm.v2i12017.51-62

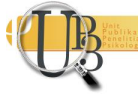


(McCullough, dkk., 1997; McCullough, dkk., 1998 McCullough, 2000; Synder \& Lopez, 2002). Forgiveness juga melibatkan proses psikologis yang meliputi adanya empati, atribusi dan penilaian terhadap peristiwa yang menyakitkan dan pelaku serta ruminasi terhadap adanya peristiwa yang menyakitkan(McCullough, 2001).

\section{E T O D E}

Penelitian ini menggunakan pendekatan kualitatif dengan metode studi kasus instrumental. Kriteria subjek dalam penelitian ini yaitu seorang istri yang memiliki rentang usia 18-40 tahun, pernah mengalami KDRT oleh suami dan masih bertahan dalam perkawinan. Pemilihan subjek dilakukan dengan teknik bola salju yaitu mencari informasi dari orang lain secara berantai. Penelitian ini melibatkan enam orang subjek. Tiga subjek utama merupakan istri dengan rentang usia 36-40 tahun yang mengalami KDRT oleh suami serta masih bertahan dalam perkawinan selama 14-25 tahun. Sedangkan tiga subjek tambahan merupakan anak dari subjek utama yang berusia 13-23 tahun. Metode penggalian data pada penelitian ini menggunakan teknik wawancara dan analisa data dilakukan dengan menggunakan teknik analisis tematik theory driven (Boyatziz, 1998; Fereday, 2006).

\section{HAS IL PENELITIAN}

Tabel.1 Hasil Penelitian

\begin{tabular}{|c|c|c|c|}
\hline Label & Subjek 1 & Subjek 2 & Subjek 3 \\
\hline \multicolumn{4}{|c|}{ Identitas } \\
\hline Nama & MA & NR & $\mathrm{OY}$ \\
\hline Usia & 36 tahun & 40 tahun & 38 tahun \\
\hline $\begin{array}{c}\text { Lama } \\
\text { menikah }\end{array}$ & 14 tahun & 25 tahun & 15 tahun \\
\hline \multicolumn{4}{|c|}{ Riwayat Kasus } \\
\hline $\begin{array}{l}\text { Bentuk } \\
\text { KDRT }\end{array}$ & $\begin{array}{l}\text { Tidak dinafkahi oleh } \\
\text { suami, } \\
\text { mendapatkan } \\
\text { pukulan dan } \\
\text { ancaman serta tidak } \\
\text { mengijinkan subjek } \\
\text { untuk keluar rumah. }\end{array}$ & $\begin{array}{l}\text { Tidak dinafkahi oleh } \\
\text { suami, tidak diijinkan } \\
\text { keluar kecuali dengan } \\
\text { suami dan anak, } \\
\text { mendapatkan ancaman, } \\
\text { dipukul, diejek, dan } \\
\text { dimarahi dengan kata- } \\
\text { kata. }\end{array}$ & $\begin{array}{l}\text { Tidak mengijinkan subjek untuk } \\
\text { bersosialisasi, mengawasi subjek } \\
\text { saat bekerja, mengatur urusan } \\
\text { rumah tangga, mendapatkan } \\
\text { ancaman, pukulan, mendapatkan } \\
\text { makian, pemaksaan untuk } \\
\text { menggugurkan kandungan. }\end{array}$ \\
\hline $\begin{array}{c}\text { Faktor yang } \\
\text { menyebabka } \\
\text { n KDRT }\end{array}$ & $\begin{array}{l}\text { Suami cemburu, } \\
\text { tidak dipinjamkan } \\
\text { uang, berjudi, tidak } \\
\text { disiapkan makanan }\end{array}$ & $\begin{array}{l}\text { Istri mengetahui suami } \\
\text { berselingkuh, berjudi, } \\
\text { tidak disiapkan makanan. }\end{array}$ & $\begin{array}{l}\text { Dendam dengan ibu mertua, } \\
\text { berselingkuh, karena masalah } \\
\text { pekerjaan dan masalah anak. }\end{array}$ \\
\hline $\begin{array}{l}\text { Intensitas } \\
\text { terjadinya } \\
\text { KDRT }\end{array}$ & $\begin{array}{l}\text { Satu minggu sekali, } \\
\text { kadang dua minggu } \\
\text { sekali atau sebulan }\end{array}$ & $\begin{array}{l}\text { Satu kali pemukulan dan } \\
\text { ejekan selama } 25 \text { tahun }\end{array}$ & $\begin{array}{l}\text { Satu minggu sekali dan dalam satu } \\
\text { bulan pasti mendapatkan aksi } \\
\text { kekerasan. }\end{array}$ \\
\hline
\end{tabular}

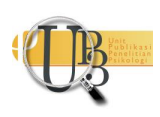




\begin{tabular}{|c|c|c|c|}
\hline & sekali & & \\
\hline $\begin{array}{l}\text { Tempat } \\
\text { terjadinya } \\
\text { KDRT } \\
\end{array}$ & Di rumah & Di rumah & $\begin{array}{l}\text { Di rumah, mobil dan di tempat } \\
\text { umum }\end{array}$ \\
\hline $\begin{array}{l}\text { Dampak } \\
\text { KDRT }\end{array}$ & $\begin{array}{c}\text { Adanya perasaan } \\
\text { takut, sedih, marah, } \\
\text { perasaan tidak kuat } \\
\text { menjalani } \\
\text { pernikahan, sakit } \\
\text { hati, sakit secara } \\
\text { fisik } \\
\end{array}$ & $\begin{array}{l}\text { Ada perasan sakit hati, } \\
\text { sedih dan menangis, } \\
\text { perasaan capek } \\
\text { menghadapi suami }\end{array}$ & $\begin{array}{c}\text { Adanya perasan sedih, takut, } \\
\text { tertekan, trauma, tulang terasa } \\
\text { sakit, tidak bisa bergerak selama } \\
\text { beberapa hari, kehilangan } \\
\text { pendengaran } \\
\text { sementara,pingsan,kehilangan } \\
\text { rasa aman dan nyaman }\end{array}$ \\
\hline \multicolumn{4}{|c|}{ Dinamika forgiveness } \\
\hline Menghindar & $\begin{array}{c}\text { Adanya keinginan } \\
\text { untuk pulang } \\
\text { kerumah orang tua } \\
\text { karena perasaan } \\
\text { tidak } \\
\text { kuat,keingingan } \\
\text { untuk bercerai, } \\
\text { diam dan menjaga } \\
\text { jarak dengan suami } \\
\text { ketika tidur } \\
\end{array}$ & $\begin{array}{c}\text { Menghindari suami } \\
\text { dengan pergi ke rumah } \\
\text { tetangga setelah dipukul } \\
\text { oleh suami dengan } \\
\text { sandal, adanya keinginan } \\
\text { untuk bercerai dan pergi } \\
\text { ke Malang dan menjauh } \\
\text { dari suami. }\end{array}$ & $\begin{array}{l}\text { Berusaha kabur dari rumah ke } \\
\text { Surabaya, ke Jogja, kemudian } \\
\text { menyewa kost selama } 1 \text { bulan, } \\
\text { mencari perlindungan pada } \\
\text { lembaga perlindungan perempuan } \\
\text { dan keinginan untuk bercerai. }\end{array}$ \\
\hline $\begin{array}{c}\text { Balas } \\
\text { dendam }\end{array}$ & $\begin{array}{l}\text { Medoakan suami } \\
\text { agar mendapatkan } \\
\text { balasan dari Tuhan }\end{array}$ & $\begin{array}{l}\text { Melawan suami dengan } \\
\text { kata-kata, sindiran, } \\
\text { adanya keinginan untuk } \\
\text { berselingkuh, dan } \\
\text { meninggalkan suami. }\end{array}$ & $\begin{array}{l}\text { Adanya harapan suami mati muda } \\
\text { karena penyakit stroke atau } \\
\text { jantung yang tidak merepotkan } \\
\text { dirinya, ingin melawan dengan } \\
\text { verbal, dan melaporkan suami ke } \\
\text { polisi hingga di penjara. }\end{array}$ \\
\hline Kebaikan & $\begin{array}{l}\text { Mengambilkan } \\
\text { suami makan dan } \\
\text { minum }\end{array}$ & $\begin{array}{l}\text { Memasak untuk suamidan } \\
\text { menemani saat suami } \\
\text { makan }\end{array}$ & $\begin{array}{c}\text { Mengingatlkan suami untuk } \\
\text { sarapan dan embuatkan sarapan } \\
\text { kepada suami }\end{array}$ \\
\hline Akomodasi & $\begin{array}{c}\text { Mau berbicara } \\
\text { dengan suami dan } \\
\text { berpergian dengan } \\
\text { suami }\end{array}$ & $\begin{array}{c}\text { Bersikap biasa dan } \\
\text { menanggapi suami serta } \\
\text { bermain dengan suami } \\
\text { dan anaknya }\end{array}$ & $\begin{array}{l}\text { Mau menanggapi suami, menjaga } \\
\text { hubungan dengan suami dan } \\
\text { menghabiskan waktu berdua }\end{array}$ \\
\hline Berkorban & $\begin{array}{c}\text { Tidak ditemukan } \\
\text { data yang } \\
\text { mendukung }\end{array}$ & $\begin{array}{l}\text { Tidak ditemukan data } \\
\text { yang mendukung }\end{array}$ & $\begin{array}{l}\text { Tidak ditemukan data yang } \\
\text { mendukung }\end{array}$ \\
\hline \multicolumn{4}{|c|}{ Proses pemaafan } \\
\hline Empati & $\begin{array}{l}\text { Adanya perasaan } \\
\text { kasihan terhdap } \\
\text { suami dan } \\
\text { mendoakan suami }\end{array}$ & $\begin{array}{l}\text { Tidak ditemukan data } \\
\text { yang mendukung }\end{array}$ & $\begin{array}{l}\text { Tidak ditemukan data yang } \\
\text { mendukung }\end{array}$ \\
\hline $\begin{array}{l}\text { Atribusi dan } \\
\text { penilaian }\end{array}$ & $\begin{array}{l}\text { Adanya penilaian } \\
\text { bahwa suaminya } \\
\text { adalah orang yang }\end{array}$ & $\begin{array}{c}\text { Adanya penilaian bahwa } \\
\text { suaminya adalah orang } \\
\text { yang suka bermain }\end{array}$ & $\begin{array}{l}\text { Menilai bahwa suami adalah tipe } \\
\text { difficult person yang selalu } \\
\text { menimbulkan masalah, menilai }\end{array}$ \\
\hline
\end{tabular}

INSAN Jurnal Psikologi dan Kesehatan Mental 2017, Vol. 2(1), 51-62 


\begin{tabular}{|c|c|c|c|}
\hline & $\begin{array}{l}\text { baik saat tidak } \\
\text { marah-marah } \\
\text { terhadapnya. }\end{array}$ & $\begin{array}{l}\text { perempuan dan suka } \\
\text { berbohong. }\end{array}$ & $\begin{array}{c}\text { suami orang yang pemarah dan } \\
\text { memiliki gangguan psikotis dan } \\
\text { sudah tidak mungkin berubah }\end{array}$ \\
\hline Ruminasi & $\begin{array}{l}\text { Tidak ditemukan } \\
\text { data yang } \\
\text { mendukung }\end{array}$ & $\begin{array}{c}\text { Melamun karena } \\
\text { mengingat-ingat kejadian } \\
\text { terdahulu yang menyakiti } \\
\text { dirinya }\end{array}$ & $\begin{array}{l}\text { Mengingat kembali saat suami } \\
\text { memukul hingga pingsan, } \\
\text { mengingat saat suami berjanji } \\
\text { tidak melakukan pemukulan } \\
\text { namun kemudian terulang kembali }\end{array}$ \\
\hline \multicolumn{4}{|c|}{ Alasan untuk memaafkan dan bertahan } \\
\hline $\begin{array}{c}\text { Alasan } \\
\text { untuk } \\
\text { memaafkan }\end{array}$ & $\begin{array}{c}\text { Meyakini bahwa } \\
\text { tidak memafkan } \\
\text { suami adalah dosa, } \\
\text { dan istri } \\
\text { berkewajiban } \\
\text { memberikan nafkah } \\
\text { batin. } \\
\end{array}$ & $\begin{array}{c}\text { Saat ini subjek belum } \\
\text { dapat memaafkan suami } \\
\text { karena masih merasa } \\
\text { sakit hati. }\end{array}$ & $\begin{array}{l}\text { Adanya keyakinan bahwa ketika } \\
\text { tidak memaafkan maka doanya } \\
\text { tidak akan terkabul dan Tuhan } \\
\text { tidak memaafkan dirinya }\end{array}$ \\
\hline $\begin{array}{c}\text { Alasan } \\
\text { untuk } \\
\text { bertahan }\end{array}$ & Karena anak & Karena anak & Karena anak, mertua, dan agama \\
\hline \multicolumn{4}{|c|}{ Keberlanjutan hubugan } \\
\hline $\begin{array}{l}\text { Keberlanjuta } \\
\text { n hubungan }\end{array}$ & $\begin{array}{c}\text { Masih bertahan } \\
\text { dalam perkawinan }\end{array}$ & $\begin{array}{c}\text { Masih bertahan dalam } \\
\text { perkawinan meskipun } \\
\text { merasa lelah dengan } \\
\text { suami }\end{array}$ & Berusaha mengurus perceraian \\
\hline \multicolumn{4}{|c|}{ Faktor lain } \\
\hline situasi & $\begin{array}{l}\text { Adanya permintaan } \\
\text { maaf dari suami }\end{array}$ & $\begin{array}{l}\text { Adanya permintaan maaf } \\
\text { dari suami }\end{array}$ & $\begin{array}{l}\text { Adanya permintaan maaf dari } \\
\text { suami }\end{array}$ \\
\hline
\end{tabular}

\section{I S K U S I}

Hasil dari penelitian ini memberikan gambaran bahwa bentuk-bentuk KDRT yang dialami oleh istri meliputi adanya kekerasan fisik, psikis, ekonomi dan seksual. Kekerasan fisik meliputi adanya pemukulan sedangkan kekerasan psikologis yang dialami oleh istri yaitu adanya ancaman yang menimbulkan rasa takut; diejek oleh suami sehingga membuatnya sakit hati; merasa tertekan akibat suami yang kerap memberikan kata-kata kasar. Dalam hal kekerasan ekonomi istri harus bekerja dan memberikan nafkah kepada anak dan suami, sedangkan suami sibuk dengan aktifitas berjudi. Disaat istri bekerja dan menghasilkan uang untuk keluarga, suami kerap marah apabila istri tidak memberikan uang kepadanya, dan suamipun melakukan kontrol kepada istri dalam hal keuangan. Selain kekerasan fisik, psikis dan ekonomi, istri juga mengalami kekerasan seksual dalam bentuk pemaksaan untuk menggugurkan kandungan.

Meskipun telah mendapatkan KDRT oleh suami, namun istri yang mengalami KDRT mampu bertahan dalam perkawinan selama 14 hingga 25 tahun. Menurut Ganley (2008) beberapa faktor yang membuat korban bertahan dalam KDRT meliputi adanya perasaan takut kepada pelaku, bertahan agar tetap bersama anak, adanya faktor budaya dan agama untuk mempertahankan rumah tangga, serta adanya harapan dan keyakinan pelaku akan berubah. Berdasarkan hasil temuan dan analisis alasaan istri

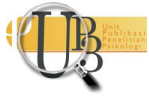


untuk bertahan dalam rumah tangga yaitu karena anak. Selain alasan anak, adanya keyakinan terhadap agama yang tidak mengijinkan umatnya bercerai, dan adanya perasaan kasihan terhadap mertua yang telah baik terhadapnya pun menjadi alasan untuk bertahan dalam perkawinan.

Bertahannya korban KDRT dalam perkawinan juga dapat dipahami dengan menggunakan teori lingkaran kekerasan, dalam KDRT yang terdiri dari 3 tahap, diantaranya: 1) munculnya ketegangan, 2) tahap pemukulan akut, 3) tahap bulan madu (Walker, 1992). Pada tahapan menculnya ketegangan yang ditandai dengan adanya pertengkaran dalam rumah tangga akan menimbulkan kekerasan kecil, sedangkan pada tahapan ke-2 kekerasan yang terjadi semakin parah ditandai dengan tindakan memukul, menampar, mendorong, mencekik atau menyerang menggunakan senjata. Selanjutnya ketika kekerasan sudah selesai, suamipun menyesali perbuatannya dan menunjukan sikap yang baik terhadap istri seperti merayu, berjanji tidak akan mengulangi perbuatan, dan meminta maaf terhadap istrinya atas perbuatan yang telah dilakukan (Saraswati, 2006).

Pada fase bulan madu inilah yang kemudian memiliki pengaruh besar dalam proses memaafkan (Rahayuningsih, 2011). Berdasarkan teori lingkaran KDRT, ketiga fase kekerasan akan berlangsung terus-menerus dan kesalahan yang sama akan terulang kembali meskipun pelaku sudah meminta maaf terhadap pasangannya pada fase bulan madu. Istri yang luluh dan mau memaafkan suami pun akan menerima kembali kekerasan yang sebelumnya didapatkannya karena memaafkan akan membuka peluang untuk mengulangi kekerasan yang dialami, namun seseorang yang mampu memaafkan akan menunggu dengan penuh harapan bahwa pelaku akan berubah sehingga kekerasan tidak akan terulang kembali (Subkoviak, Enright, Wu, Gassin, Freedman, Olson, \& Sarinopoulos, 1995).

Kekerasan yang dialami oleh istri yang mengalami KDRT, menimbulkan dampak fisik dan psikologis. Dampak fisik meliputi gangguan pada kesehatan seperti gangguan pada penglihatan dan pendengaran serta sakit pada punggung yang membuatnya tidak bisa bergerak selama beberapa hari. Hal tersebut sesuai dengan yang diungkapkan oleh Kumar (2012) bahwa kekerasan fisik yang dilakukan oleh pelaku menyebabkan korban mengalami luka fisik, sakit pungggung, pingsan dan penyakit kronis lainnya. Sedangkan dampak psikologis yang dialami meliputi adanya afek negatif berupa perasan sedih, perasaan tidak adil, jengkel, marah, takut, tertekan, sakit hati dan perasaan tidak kuat menjalani pernikahan. Selanjutnya perasaan takut, tertekan, dan tidak kuat menjalani pernikahan mendorongnya untuk menghindari suami dengan cara menjaga jarak dengan suami, kabur dari rumah dan keinginan untuk bercerai. Kemudian adanya perasaan marah, jengkel, sakit hati dan perasaan tidak adil mendorongnya untuk berkeinginan membalas dendam dengan cara membalas dengan omongan yaitu mengatakan keburukan suami, melawan omongan suami, berharap suami akan mati muda dan mendapatkan balasan yang setimpal hingga memita ganti rugi dengan melaporkan suami ke penjara. Hal tersebut seperti yang diungkapkan oleh McCullough (2001) bahwa adanya feelling hurt perceive attack berupa perasaan takut dan khawatir akan menimbulkan avoidance motivation seperti menghindari pelaku, dan righteous indignation yaitu perasaan marah dan jijik akan membuat korban memiliki revenge motivation yaitu keinginan membalas dendam.

Meskipun telah mendapatkan KDRT secara berulang-ulang, istri yang mengalami KDRT mau memaafkan suami karena adanya faktor anak dan melihat perilaku suami yang kerap berubah setelah melakukan KDRT seperti menunjukan rasa bersalah dengan memijit, memeluk mapun merayu korban hingga meminta maaf terhadap korban atas kekerasan yang terjadi. Saat pelaku meminta maaf, istri pun kemudian mau memaafkan suami dan memiliki harapan bahwa suami akan berubah. Namun pada kenyataannya, perubahan yang diharapkan tidaklah terjadi karena pelaku selalu mengulangi

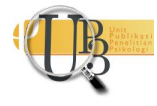


kesalahan yang sama meskipun telah meminta maaf. Meskipun demikian, pemaafan yang dilakukan oleh istri juga dipengaruhi oleh adanya keyakinan bahwa ketika ia tidak memaafkan maka doa yang ia panjatkan kepada Tuhan tidak akan terkabul, dan Tuhan tidak akan mengampuni dirinya ketika ia tidak memaafkan suami. Serta adanya nilai yang diyakini bahwa seorang istri harus memberikan maaf terhadap suami. Pada penelitian ini ditemukan bahwa istri yang mengalami KDRT dapat merubah dorongan negatif seperti rasa marah dan ingin membalas dendam kearah yang lebih positif yaitu mau berkomunikasi dengan suami, dan menyiapkan makanan untuk suami. Adanya perubahan ke arah yang lebih positif ditemukan karena adanya faktor situasi dimana suami mau memulai pembicaraan, meminta maaf, bahkan berperilaku baik kepada istri yaitu dengan memijit atau dengan memberian waktu untuk bersantai. Faktor situasi menurut McCullough (2000) adalah melingkupi adanya permintaan maaf dari pelaku kepada korban sehingga hal tersebut akan mempengaruhi korban mau memaafkan pasangan.

Dinamika forgiveness yang ditemukan pada penilitian ini yaitu adanya perubahan motivasi dari avoidance motivation dan revenge motivation membentuk benevolence motivation melalui akomodasi yaitu usaha untuk menahan dorongan yang membuat hubungan menjadi destruktif dengan cara bertindak konstruktif kepada pelaku dengan menanggapi pelaku saat berbicara dan adanya niat baik untuk menjaga hubungan. Hal tersebut seperti yang diungkapkan oleh McCullough (2000) bahwa pemaafan bukan hanya sekedar motivasi namun juga melibatkan perubahan prososial pada motivasi, sehingga seseorang mampu mengurangi motivasi menghindari dan balas dendam dengan bersikap baik. Rusbult, dkk (1991, dalam McCullough, 2000) mengungkapkan bahwa perubahan prososial melibatkan adanya akomodasi dan keinginan untuk berkoban, namun pada penelitian ini belum ditemukan data mengenai keinginan berkorban yang dilakukan oleh istri. Penulis menemukan bahwa meskipun istri mendapatkan KDRT oleh suami, namun istri yang mengalami KDRT tetap menunjukan adanya niat dan perilaku untuk melayani suami dengan cara menyiapkan masakan untuk suami dan anak, dalam hal ini niat baik dari istri merupakan benovelence motivation, yaitu adanya motivasi untuk berdamai dengan suami. Meskipun demikian, tindakan untuk melayani suami sebenarnya merupakan kewajiban dari seorang istri. Hal tersebut sesuai yang diungkapkan oleh Kartono (1992) bahwasanya peran dan tugas istri dalam rumah tangga salah satunya adalah mengatur dan mengerjakan pekerjaan rumah tangga.

Meskipun istri yang mengalami KDRT mengungkapkan bahwa mereka mampu memaafkan suami, namun istri yang mengalami KDRT masih sulit melakukan pemaafan terhadap suami. Hal tersebut disebabkan oleh adanya ruminasi yaitu pikiran yang berulang-ulang terhadap kesalahan yang dilakukan oleh suami, seperti suami kerap berjudi dan berselingkuh, dan hal tersebut membuat istri masih memiliki sakit hati yang mendalam. Istri yang mengalami KDRT juga memiliki atribusi dan penilaian yang negatif terhadap suami, mereka tidak percaya suami akan berubah, karena kesalahan yang dilakukan selalu berulang-ulang meskipun mereka telah meminta maaf. Hal tersebut pun membuat istri sulit untuk mempercayai suami. Permintaan maaf yang dilakukan suami tidak menimbulkan adanya empati karena KDRT yang dialaminya berulang-ulang sehingga adanya ruminasi, atribusi dan penilaian negatif yang menghambat istri untuk dapat memaafkan suami.

Istri yang mengalami KDRT pada penelitian ini ditemukan tidak kuat dalam menjalani perkawinan dengan suami. Hal tersebut menunjukan bahwa istri masih memiliki afek negatif terhadap hubungannya. Selain hal tersebut juga ditemukan bahwa istri memiliki keinginan yang kuat untuk melakukan balas dendam kepada suami dengan cara melawan suami dan melaporkan suami ke penjara. Hal tersebut menunjukan bahwa istri masih memiliki dorongan yang negatif terhadap suami.

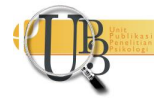


Berdasarkan data yang ditemukan, maka istri yang mengalami KDRT lebih merasakan dorongan negatif terhadap pelaku, sehingga dapat dikatakan bahwa istri belum memaafkan suaminya. Hal ini sesuai dengan yang diungkapkan oleh McCullough (2000) bahwa saat seseorang tidak memaafkan pelaku, maka persepsi seseorang kepada pelaku dan kejadian yang ia alami akan mengarahkan orang tersebut kepada hubungan yang destruktif dengan ditandai adanya level yang tinggi untuk membalas dendam dan menghindari pelaku. Istri belum memaafkan karena tingginya level menghindari dan balas dendam. Lebih lanjut Worthington, dkk (2007) mengungkapkan bahwa tidak memaafkan ditandai dengan adanya ruminasi, rasa marah, dan perasaan bermusuhan kepada pasangan.

\section{S I M P U L A N}

Forgiveness pada istri yang mengalami KDRT meliputi dorongan untuk menghindari, membalas dendam dan dorongan kebaikan yang meliputi akomodasi. Faktor-faktor yang mendorong istri yang mengalami KDRT memaafkan adalah karena anak dan adanya keyakinan individu terhadap agama. Istri yang mengalami KDRT memilih untuk memaafkan dan bertahan dalam perkawinan karena individu merasa kasihan terhadap anak jika mereka harus bercerai dengan suami, adanya perubahan suami menjadi baik juga membuat istri yang mengalami KDRT memaafkan pasangan. KDRT akan menimbulkan afek negatif seperti perasaan takut, tertekan, sakit hati dan tidak kuat menjalani pernikahan. Hal tersebut akan mendorong istri yang mengalami KDRT memiliki keinginan untuk menghindari pelaku. Selain hal tersebut adanya perasaan jengkel dan tidak adil akan mendorong istri yang mengalami KDRT untuk membalas dendam kepada pelaku.

Dinamika forgiveness terjadi ketika adanya pengurangan dorongan untuk menghindari pelaku dan pengurangan dorongan untuk membalas dendam kearah positif dengan melibatkan akomodasi yaitu keinginan seseorang untuk mengurangi dorongan negatif yang menyebabkan rusaknya hubungan kearah yang lebih konstruktif seperti adanya keinginan untuk menanggapi pelaku, mau berbicara dengan pelaku dan menjaga hubungan dengan pelaku. Dinamika forgiveness yang ditemukan pada penelitian ini berbeda-beda, dimana istri yang mengalami KDRT yang parah akan lebih sulit memaafkan dari pada istri yang mengalami KDRT yang ringan.

Adanya permintaan maaf dari pelaku tidak membuat istri yang mengalami KDRT merasakan empati karena adanya atribusi dan penilaian negatif terhadap pelaku, meskipun istri yang mengalami KDRT memiliki niat baik untuk melayani suami, namun hal tersebut merupakan tugas dari seorang istri di dalam rumah tangga. Penelitian ini menemukan bahwa istri yang mengalami KDRT sulit memaafkan pelaku karena lebih banyak mengalami afek negatif berupa dorongan yang kuat untuk menghindari dan berpisah dari pelaku serta keinginan untuk membalas dendam, adanya ruminasi yaitu ingatan akan peristiwa yang dialami dan atribusi serta penilaian negatif mengenai pelaku.

\section{PUST A KA A C UA N}

Boyatzis, R. E. (1998). Transforming qualitative information: Thematic analysis and code development. London: SAGE Publication.

Chhikara, P., Jakhar, J., Malik, A., Singla, K., \& Dhattarwal, S. K. (2013). Domestic Violence: The Dark Truth of Our Society. Journal of Indian Academy of Forensic Medicine, 35(1), 71-75.

Enright, R. D., and the Human Development Study Group. (1991). The moral development of 
forgiveness. In W. Kurtines \& J. Gewirtz (Eds.), Handbook of moral behavior and development,(Vol. 1, pp. 123-152). Hillsdale NJ: Erlbaum.Enright, R.D. \& North, J. (1998). Introducing Forgiveness. In R.D. Enright \& J. North (Ed). Exploring Forgiveness. Madison: The University of Wisconsin Press.

Family Crisis Center. (2010). The cycle of violence. Diakses pada tanggal 23 Januari 2016

dari http://www.1736familycrisiscenter.org/pdf/Cycle\%20of\%20Violence v3.pdf

Fereday, J., \& Muir-Cochrane, E. (2006). Demonstrating rigor using thematic analysis: A hybrid approach of inductive and deductive coding and theme development. International journal of qualitative methods, 5(1), 80-92.

Fincham, F.D. (2010). Forgiveness: Integral to a Science of Close Relationship?. Inaugural Herzliya Symposium on Personality and Social Psychology Prosocial Motives, Emotions, and Behaviour.

Fincham, F. D., Beach, S. R., \& Davila, J. (2007). Longitudinal relations between forgiveness and conflict resolution in marriage. Journal of Family Psychology, 21(3), 542.

Ganley, A.L. (2008). Understanding Domestic Violence. Diakses pada tanggal 3 Januari 2016 dari http://www.familyjusticecenter.org/file-library/dv-101-understanding-domestic-violence-ganley2008-pdf/

Harris, A.H.S., \& Thoresen, C.E. (2005). Forgiveness, unforgiveness, health, and disease. In E.L.

Worthington (Ed.) Handbook of forgiveness. NY: Brunner-Routledge. Pp321-333

Kartono, K. (1992). Psikologi Wanita mengenal Gadis, Remaja, \& Wanita Dewasa. Bandung: CV Mandar Maju.

Kodir. F.A \& Mukarnawati, U.A. (2008). Referensi bagi Hakim Peradilan Agama tentang Kekerasan dalam Rumah Tangga. Jakarta: Komnas Perempuan.

Komnas Perempuan. (2013). Catatan Tahunan tentang kekerasan Terhadap Perempuan: Jakarta

Kumar, R. (2012). Domestic Violence and Mental Health. Delhi Psychiatry Journal, 15(2), 274-278

McCullough, M. E., Bellah, C. G., Kilpatrick, S. D., \& Johnson, J. L. (2001). Vengefulness: Relationships with forgiveness, rumination, well-being, and the Big Five. Personality and Social Psychology Bulletin, 27(5), 601-610.

McCullough, M. E. (2000). Forgiveness as human strength: Theory, measurement, and links to wellbeing. Journal of Social and Clinical Psychology, 19(1), 43-55.

McCullough, M. E. (2001). Forgiveness: Who does it and how do they do it?. Current Directions in Psychological Science, 10(6), 194-197.

McCullough, M. E., Rachal, K. C., Sandage, S. J., Worthington Jr, E. L., Brown, S. W., \& Hight, T. L. (1998). Interpersonal forgiving in close relationships: II. Theoretical elaboration and measurement. Journal of personality and social psychology, 75(6), 1586.

McCullough, M. E., Rachal, K. C., Sandage, S. J., Worthington Jr, E. L., Brown, S. W., \& Hight, T. L. (1998). Interpersonal forgiving in close relationships: II. Theoretical elaboration and measurement. Journal of personality and social psychology, 75(6), 1586. 
McCullough, M. E., Pargament, K. I., \& Thoresen, C. E. (Ed). (2001). Forgiveness: Theory, research, and practice. Guilford Press.

Rahayuningsih, T. B. (2011). Forgiveness (Pemberian Maaf) terhadap Pelaku Kekerasan Dalam Rumah Tangga Pada Istri (Studi Kasus Pada Perempuan Korban Kekerasan dalam Rumah tangga di Kota Magelang). Diakses pada tanggal 11 Oktober dari http://lib.unnes.ac.id/11825/

Saraswati, R. (2006). Perempuan dan Penyelesaian Kekerasan dalam Rumah Tangga. Bandung: PT Citra Aditya Bakti.

Sartika, D., \& Amalia, N. F. (2014). Forgiveness in Wives Experiencing Domestic Violence. International Journal of Social Science and Humanity, 4(3), 238.

Silalahi, K. \& Meinarno, E.A. (2010). Keluarga Indonesia Aspek dan Dinamika Zaman. Jakarta: Rajawali Pers

Sonda, M. (2010). Dampak Kekerasan dalam Rumah Tangga Terhadap Gangguan Kesehatan Reproduksi Wanita di Rumah Sakit Bhayangkara Makasar Tahun 2010. Jurnal Media Kebidanan Poltekes Makasar, 2(2).

Subkoviak, M. J., Enright, R. D., Wu, C. R., Gassin, E. A., Freedman, S., Olson, L. M., \& Sarinopoulos, I. (1995). Measuring interpersonal forgiveness in late adolescence and middle adulthood. Journal of adolescence, 18(6), 641.

Smith, A. (2005). The "Monster" in All of Us: When Victims Become Perpetrators. Diakses pada tanggal 19 Januari 2016 di http://scholarship.law.georgetown.edu/facpub/219

Synder, C.R. \& Lopez, S.J. (2002). Handbook of Positive Psychology. New York: Oxford University Press.

Walker, L. E. (1992). Battered women syndrome and self-defense. Notre Dame Journal of Law, Ethics \& Public Policy, 6(2), 321-334.

Worthington Jr, E. L. (Ed.). (2007). Handbook of forgiveness. New York: Routledge.

Worthington, E. L., Witvliet, C. V. O., Pietrini, P., \& Miller, A. J. (2007). Forgiveness, health, and wellbeing: A review of evidence for emotional versus decisional forgiveness, dispositional forgivingness, and reduced unforgiveness. Journal of Behavioral Medicine, 30(4), 291-302. 